\title{
Performance of CLOU process in the combustion of different types of coal with $\mathrm{CO}_{2}$ capture
}

\author{
I. Adánez-Rubio, A. Abad*, P. Gayán, L. F. de Diego, F. García-Labiano, J. Adánez \\ Instituto de Carboquímica (ICB-CSIC), Miguel Luesma Castán 4, 50018-Zaragoza, \\ Spain
}

*e-mail: abad@icb.csic.es

\begin{abstract}
Chemical-Looping with Oxygen Uncoupling (CLOU) process is a ChemicalLooping Combustion (CLC) technology that allows the combustion of solid fuels using
\end{abstract} oxygen carriers with inherent $\mathrm{CO}_{2}$ separation The oxygen necessary for the fuel combustion is supplied by a solid oxygen carrier, which contains a metal oxide. The oxygen carrier circulates between two interconnected fluidized reactors: the fuel and the air reactor. In the CLOU process, the oxygen carrier releases gaseous oxygen in the fuel reactor which burns coal as in common combustion with air, so the $\mathrm{CO}_{2}$ generated is undiluted with $\mathrm{N}_{2}$. The reduced oxygen carrier is oxidized by air to the initial metal oxide in the air reactor, then being ready to start a new cycle. The aim of this work is to study the performance of the CLOU process using coals of different rank. Experiments were carried out in a continuously operated $1.5 \mathrm{~kW}_{\text {th }}$ unit. Particles prepared by spray drying containing 60 wt.\% $\mathrm{CuO}$ were used as oxygen carrier. Four coals of different rank (anthracite, low volatile bituminous, medium volatile bituminous and lignite) were used as fuel. Besides, the temperature in the fuel reactor was varied between 900 and $950{ }^{\circ} \mathrm{C}$. In all the experiments there was complete combustion of the coal to $\mathrm{CO}_{2}$ and $\mathrm{H}_{2} \mathrm{O}$, without any unburnt product. The carbon capture efficiency greatly depends on the coal rank and fuel reactor temperature. High carbon capture efficiencies were obtained for Lignite and Medium Volatile Bituminous coals. The maximum capture efficiency was $99.3 \%$ at $950{ }^{\circ} \mathrm{C}$ with Lignite. The analysis of the experimental results was used to evaluate the effect of the coal rank in a CLOU system when a carbon separation system is included. At $925{ }^{\circ} \mathrm{C}$, the solid inventory needed to reach $95 \%$ of $\mathrm{CO}_{2}$ capture efficiency with a carbon separation system of $90 \%$ of efficiency is $45 \mathrm{~kg} / \mathrm{MW}_{\text {th }}$ using Lignite, $85 \mathrm{~kg} / \mathrm{MW}_{\text {th }}$ using MV Bituminous, $140 \mathrm{~kg} / \mathrm{MW}_{\text {th }}$ using LV Bituminous and $490 \mathrm{~kg} / \mathrm{MW}_{\text {th }}$ using Anthracite. It must be pointed out the low solid inventories needed in the CLOU process for the different coal rank analyzed in this work.

Keywords: Carbon capture, combustion, coal, CLOU, copper, chemical-looping. 


\section{Introduction}

According to the IPCC report on mitigation of climate change (IPCC, 2005), in order to stabilize $\mathrm{CO}_{2}$ concentration in the atmosphere Carbon Capture and Storage (CCS) would contribute with $15-55 \%$ to the cumulative mitigation effort worldwide until 2100. CCS is a process involving the separation of $\mathrm{CO}_{2}$ emitted by industry and energyrelated sources, and its storage for isolation from the atmosphere over a long term. Chemical-Looping Combustion process (CLC) has been suggested among the best alternatives to reduce the economic cost of $\mathrm{CO}_{2}$ capture (Kerr, 2005) and to reduce energy penalty compared with other $\mathrm{CO}_{2}$ capture process (Kvamsdal et al., 2007). In this process, $\mathrm{CO}_{2}$ is inherently separated from other combustion products, $\mathrm{N}_{2}$ and unused $\mathrm{O}_{2}$, through the use of a solid oxygen carrier. Thus no energy is expended for the $\mathrm{CO}_{2}$ separation. The CLC process has been demonstrated for combustion of gaseous fuels such as natural gas or syngas in 10 to $140 \mathrm{~kW}_{\text {th }}$ units using oxygen carrier materials based on Ni (Linderholm et al., 2009; Kolbitsch et al., 2009; Ryu et al., 2010), $\mathrm{Cu}$ (Adánez et al., 2006) and Fe (Pröll et al., 2009). All these oxygen carriers have been reviewed by Adánez et al. (2012).

However, for energy generation is highly relevant the direct use of solid fuels in the CLC concept because solid fuels are considerably more abundant and less expensive than natural gas. In the Chemical-Looping Combustion with solid fuels, the fuel is physically mixed with the oxygen carrier in the fuel reactor. The in-situ gasification of the solid fuel, e.g. coal, biomass or solid wastes, has been proposed using steam or $\mathrm{CO}_{2}$ as gasification agent (Cao and Pan, 2006; Scott et al., 2006). This process has been demonstrated in units of $10 \mathrm{~kW}_{\text {th }}$ with coal or biomass (Berguerand and Lyngfelt, 2008; Shen et al., 2009). The limitation in the solid fuel conversion in the CLC with solid fuels comes from the slow gasification process (Berguerand and Lyngfelt, 2008; Cuadrat et al., 2012a). To increase the gasification rate, temperatures higher than 1000 ${ }^{\circ} \mathrm{C}$ has been proposed (Berguerand and Lyngfelt, 2009).

To overcome the low reactivity of the char gasification step in the direct solid fuelled Chemical-Looping Combustion, an alternative process, Chemical-Looping with Oxygen Uncoupling (CLOU), was recently proposed by Mattisson et al. (2009a). They made use of the idea first proposed by Lewis and Gilliland (1954) to produce $\mathrm{CO}_{2}$ from solid carbonaceous fuels by using gaseous oxygen produced by the decomposition of $\mathrm{CuO}$. Chemical-Looping with Oxygen Uncoupling (CLOU) process is based on the strategy 
of using oxygen carrier materials which release gaseous oxygen and thereby allowing the solid fuel to burn with gas phase oxygen. These materials can be also regenerated at high temperatures.

Fig. 1 shows a schematic diagram of a CLOU system. In the fuel reactor the fuel conversion is produced by different reactions. First the oxygen carrier releases oxygen according to:

$2 \mathrm{Me}_{\mathrm{x}} \mathrm{O}_{\mathrm{y}} \leftrightarrow 2 \mathrm{Me}_{\mathrm{x}} \mathrm{O}_{\mathrm{y}-1}+\mathrm{O}_{2}$

and the solid fuel begins to devolatilize producing a carbonaceous solid residue (char, mainly composed by carbon and ash) and volatile matter as gas product:

Coal $\rightarrow$ Volatile matter + Char $(\mathrm{C})$

Then, volatiles and char are burnt as in usual combustion with gaseous oxygen according to reactions (3) and (4):

Volatile matter $+\mathrm{O}_{2} \rightarrow \mathrm{CO}_{2}+\mathrm{H}_{2} \mathrm{O}$

Char $(\mathrm{C})+\mathrm{O}_{2} \rightarrow \mathrm{CO}_{2}$

After steam condensation, a pure $\mathrm{CO}_{2}$ stream can be obtained from the fuel reactor. The reduced oxygen carrier is transported to the air reactor, where the oxygen carrier is regenerated to the initial oxidation stage with the oxygen of the air, and being ready for a new cycle. Ideally, the exit stream of the air reactor contains only $\mathrm{N}_{2}$ and unreacted $\mathrm{O}_{2}$. The heat release over the fuel and air reactors is the same as for conventional combustion. Therefore CLOU process has a low energy penalty for $\mathrm{CO}_{2}$ separation and low $\mathrm{CO}_{2}$ capture costs are expected.

In the CLOU process, the slow gasification step on the direct solid fuel CLC is avoided, giving a much faster solid conversion (Mattisson et al., 2009b; Eyring et al. 2011; Abad et al 2012). It was found that the conversion rate of the solid fuel was increased by a factor of 45 for petroleum coke (Mattisson et al., 2009a) or by 60 for a bituminous coal (Abad et al., 2012) at CLOU conditions oxygen carriers in comparison to those measured with oxygen carrier which do not have oxygen uncoupling properties. Moreover, the combustion of the fuel consumes the oxygen generated by the oxygen carrier and improves the decomposition reaction of the metal oxide particles (AdánezRubio et al., 2012a). As consequence, a solids inventory in the fuel reactor between 120 and $200 \mathrm{~kg} / \mathrm{MW}_{\text {th }}$ were estimated for CLOU process (Mattisson et al., 2009a, Eyring et al., 2011). A minimum solids inventory was estimated by Adánez-Rubio et al. (2012a) as low as $50 \mathrm{~kg} / \mathrm{MW}_{\text {th. }}$. These solids inventories are much lower than the ones required 
in a CLC system with solid fuels, $2000 \mathrm{~kg} / \mathrm{MW}_{\text {th }}$ for Fe-based particles (Leion et al., 2007; Cuadrat et al., 2012b and 2012c).

Thus, a special requirement is needed for the oxygen carrier to be used in the CLOU process in comparison to oxygen carriers for normal CLC, where the fuel reacts directly with the solid oxygen carrier without any release of gas phase oxygen. Only those metal oxides that have a suitable equilibrium partial pressure of oxygen at temperatures of interest for combustion $\left(800-1200{ }^{\circ} \mathrm{C}\right)$ can be used as oxygen carrier materials in the CLOU process. Besides, this $\mathrm{O}_{2}$ release must be reversible in order to oxidize the oxygen carrier in the air reactor and regenerate the material. $\mathrm{CuO} / \mathrm{Cu}_{2} \mathrm{O}, \mathrm{Mn}_{2} \mathrm{O}_{3} / \mathrm{Mn}_{3} \mathrm{O}_{4}$, and $\mathrm{Co}_{3} \mathrm{O}_{4} / \mathrm{CoO}$ have been identified as redox pairs with capacity to evolve oxygen at high temperature (Mattisson et al., 2009a). Up to date, there are only a small number of works in the literature for CLOU process dealing with the use of $\mathrm{Cu}$ - and $\mathrm{Mn}-$ based materials.

Regarding the use of manganese oxides for CLOU process, several Mn-based particles supported on $\mathrm{Fe}_{2} \mathrm{O}_{3}, \mathrm{NiO}, \mathrm{SiO}_{2}$ or $\mathrm{MgO}$ and a perovskite type material $\left(\mathrm{CaMn}_{\mathrm{x}} \mathrm{Ti}_{1-\mathrm{x}} \mathrm{O}_{3}\right)$ have been tested in a batch fluidized bed at Chalmers University of Technology (Azimi et al., 2011; Leion et al., 2009a; Shulman et al., 2009 and 2011). Good oxygen uncoupling and mechanical properties, as well as high reactivity with methane were showed for a $\mathrm{Mn} / \mathrm{Fe}$ material and perovskite type material. These two promising materials were further tested in a continuous facility with methane as fuel (Rydén et al., 2011a and 2011b).

In general, Cu-based materials have faster release of oxygen than Mn-based particles (Leion et al., 2009a). Preliminary experiments in a batch fluidized-bed reactor were conducted using $\mathrm{Cu}$-based materials with $\mathrm{Al}_{2} \mathrm{O}_{3}$ or $\mathrm{ZrO}_{2}$ as supporting materials (Leion et al., 2009b; Mattisson et al., 2009a and 2009b), and a high fractional conversion rate of char was found for several carbonaceous materials, including petcoke, coal or biomass. However, they found some defluidization phenomena with $\mathrm{Cu}$-based particles during some parts of the experiments.

In the research group of ICB-CSIC, a screening study considering 25 different $\mathrm{Cu}$-based oxygen carriers was done to select appropriate materials for CLOU process (AdánezRubio et al., 2011; Gayán et al., 2012). Particles prepared by different methods and using several $\mathrm{CuO}$ contents and supporting materials were tested. Reactivity of materials was analyzed in a TGA, whereas mechanical stability and fluidization 
properties were studied in a batch fluidized bed. Two promising $\mathrm{Cu}$-based oxygen carriers prepared by pelletizing by pressure (60 wt.\% $\mathrm{CuO}$ supported on $\mathrm{MgAl}_{2} \mathrm{O}_{4}$, and 40 wt.\% $\mathrm{CuO}$ supported on $\mathrm{ZrO}_{2}$ ) were selected according to their high reactivity, low attrition rate and avoidance of agglomeration during successive redox cycles by alternating nitrogen and air.

After the screening tests, a batch of 60 wt.\% of $\mathrm{CuO}$ supported on $\mathrm{MgAl}_{2} \mathrm{O}_{4}$ was prepared by spray drying. The proof of the concept of the CLOU process was demonstrated using this material as oxygen carrier (Abad et al. 2012) burning a bituminous coal in a $1.5 \mathrm{~kW}_{\text {th }}$ continuously operated unit consisting of two interconnected fluidized-bed reactors. The effects of fuel reactor temperature, coal feeding rate, and solids circulation flow rate on the combustion, and $\mathrm{CO}_{2}$ capture efficiencies were investigated. Fast oxygen generation rate by the oxygen carrier and full combustion of coal was attained in the plant using a solids inventory in the fuel reactor of $235 \mathrm{~kg} / \mathrm{MW}_{\text {th. }}$. In conjunction, values close to $100 \%$ in carbon capture efficiency were obtained at $960{ }^{\circ} \mathrm{C}$. An analysis about the evolution of physical and chemical characteristics of this oxygen carrier with the operational time is summarized in a previous work (Adánez-Rubio et al., 2012b).

Leion and coworkers (Leion et al, 2009b) using six different solid fuels showed that the differences in reactivity between solid fuels were more pronounced in ChemicalLooping Combustion than in CLOU process. This fact was explained by the difference in the reaction paths between both processes. In CLC, the limiting reaction is the slow gasification of the fuel, whereas in CLOU the release of oxygen from the oxygen carrier particle becomes rate limiting.

The aim of this work was to investigate the performance of the CLOU process for different type of coals ranging from lignite to anthracite. The effect of the coal rank and the fuel reactor temperature on the combustion efficiency and carbon capture efficiency was investigated in a continuously operated CLOU unit. The results obtained are analyzed and discussed in order to be useful for the scale-up of a CLOU process fuelled with coal. 


\section{Experimental section}

\subsection{The Cu-based oxygen carrier}

The oxygen carrier was a $\mathrm{Cu}$-based material prepared by spray drying. Oxygen carrier particles were manufactured by VITO (Flemish Institute for Technological Research, Belgium) using $\mathrm{MgAl}_{2} \mathrm{O}_{4}$ spinel (Baikowski, S30CR) and $\mathrm{CuO}$ (Panreac, PRS) as raw materials. The $\mathrm{CuO}$ content was $60 \mathrm{wt} . \%$. The particles were calcined $24 \mathrm{~h}$ at $1100{ }^{\circ} \mathrm{C}$. The particle size of the oxygen carrier was $+0.1-0.2 \mathrm{~mm}$. From now on, the oxygen carrier was named as $\mathrm{Cu} 60 \mathrm{MgAl}$. Table 1 shows the main properties of this material.

Physical and chemical characterization was carried out with these particles. The copper content was determined by complete reduction in TGA using 15 vol.\% $\mathrm{H}_{2}$ at $850{ }^{\circ} \mathrm{C}$. The oxygen transport capability, $R_{O C}$, was calculated in TGA in nitrogen atmosphere as $R_{O C}=\left(m_{o x}-m_{r e d}\right) / m_{o x}$, being $m_{o x}$ the mass of fully oxidized particles and $m_{r e d}$ in the reduced form, i.e. when all $\mathrm{CuO}$ has been reduced to $\mathrm{Cu}_{2} \mathrm{O}$. The crushing strength was determined by measuring the force needed to fracture a particle using a Shimpo FGN$5 \mathrm{X}$ crushing strength apparatus. The crushing strength was taken as the average value of at least 20 measurements. The skeletal density, i.e. the density of solids excluding the pores, was determined by He picnometry in a Micromeritics AccuPyc II 1340. The surface area of the oxygen carrier was determined by the Brunauer-Emmett-Teller (BET) method by adsorption/desorption of nitrogen at $77 \mathrm{~K}$ in a Micromeritics ASAP2020 (Micromeritics Instruments Inc.), whereas the pore volumes were measured by $\mathrm{Hg}$ intrusion in a Quantachrome PoreMaster 33. The identification of crystalline chemical species was carried out by powder X-ray diffractometer Bruker AXS graphite monochromator.

Preliminary results showed that this material had adequate values of reactivity and oxygen transport capacity in fluidized-bed conditions (Adánez-Rubio et al., 2012a). In tests carried out in a continuous CLOU unit burning coal with this material, high combustion rate with complete combustion to $\mathrm{CO}_{2}$ and $\mathrm{H}_{2} \mathrm{O}$ were obtained using a low solids inventory in the fuel reactor (Abad et al., 2012).

\subsection{Coals}

Four different coals were used for CLOU experiments with the Cu60AlMg oxygen carrier. A Lignite from Teruel basin (Spain), a Medium Volatile Bituminous coal from South Africa, a Low Volatile Bituminous coal from Checkia, and an Anthracite from El 
Bierzo (Spain) were used with the aim to cover a wide range of coals. Main properties of selected coals (proximate and ultimate analysis and LHV) are showed in Table 2. Note the high ash contents of lignite $(25.2 \%)$ and anthracite $(31.6 \%)$ coals. The coal particle size used for this study was $+0.2-0.3 \mathrm{~mm}$ with all fuels.

\subsection{TGA facility}

A thermogravimetric analyzer (TGA) was used for the determination of the coal combustion reactivity. A detailed description of the TGA can be found elsewhere (de Diego et al., 2004). The TGA consisted of a quartz tube (24 mm i.d.) placed in a mobile furnace. This furnace has two positions: upper position inside the reaction zone, and a lower position outside the reaction zone. The method developed by Adánez et al. (2001) was used to obtain the intrinsic reactivity of coal combustion. Char was prepared for each coal in the TGA. For char preparation, $5 \mathrm{mg}$ of the corresponding coal were well mixed in $45 \mathrm{~g}$ of silica sand and placed in a wire mesh basket inside the quartz reactor of the TGA at ambient temperature. A $\mathrm{N}_{2}$ flow of $25 \mathrm{~L}_{\mathrm{N}} / \mathrm{h}$ was fed into the reactor. At the same time, the furnace was heated to $900{ }^{\circ} \mathrm{C}$, but in the lower position. When the mass of the sample was stable, a quick heating was carried out using the mobile furnace. A flash devolatilization of coal occurred, in a similar way as in at CLOU unit. Devolatilization was carried out at $900{ }^{\circ} \mathrm{C}$ during $30 \mathrm{~s}$. After that, the coal sample was cooled to ambient temperature. The char reactivity was determined at $500{ }^{\circ} \mathrm{C}$ in air atmosphere using $25 \mathrm{~L}_{\mathrm{N}} / \mathrm{h}$. Experimental conditions were selected to avoid film gas transfer and internal diffusion resistances as much as possible trying to obtain intrinsic reactivities.

\subsection{ICB-CSIC-s1 unit for the CLOU process}

A schematic view of the experimental set-up used is shown in Fig. 2. The set-up was basically composed of two interconnected fluidized-bed reactors -the air and fuel reactors- joined by a loop seal in the lower and a riser for solids transport from the air reactor to the fuel reactor. A cyclone recovers the solid entrained from the riser. A solids valve controls the solids circulation flow rate in the system. The reactors operate at slightly higher than atmospheric pressure, taking into consideration the pressure drops in the beds and pipes to stack. The fuel reactor (1) consisted of a bubbling fluidized bed with $50 \mathrm{~mm}$ of inner diameter and $200 \mathrm{~mm}$ bed height. $\mathrm{N}_{2}$ was used as fluidizing gas. $\mathrm{N}_{2}$ instead $\mathrm{CO}_{2}$ was used as fluidizing gas in order to improve the accuracy for 
calculation of carbon burnt in the fuel reactor. In a previous work it was determined that the fluidization agent does not have any influence on the oxygen carrier behaviour (Adánez-Rubio et al., 2011; Gayán et al., 2012). The gas flow was $186 \mathrm{~L}_{\mathrm{N}} / \mathrm{h}$, corresponding to a gas velocity of $0.11 \mathrm{~m} / \mathrm{s}$ at $900{ }^{\circ} \mathrm{C}$. The minimum fluidizing velocities of the oxygen carrier particles are $0.006 \mathrm{~m} / \mathrm{s}$ for the smallest particle size and $0.023 \mathrm{~m} / \mathrm{s}$ for the biggest one while the terminal velocities of particles are $0.40 \mathrm{~m} / \mathrm{s}$ and $1.45 \mathrm{~m} / \mathrm{s}$ respectively.

Coal (9) was fed in by a screw feeder (10) at the bottom of the bed just above the fuel reactor distributor plate in order to maximize the time that the fuel and volatile matter are in contact with the bed material. The screw feeder has two steps: the first one with variable speed to control the coal flow rate, and the second one is water cooled and it has high rotating velocity to avoid coal pyrolysis inside the screw. A small $\mathrm{N}_{2}$ flow (24 $\mathrm{L}_{\mathrm{N}} / \mathrm{h}$ ) is introduced at the beginning of the screw feeder to avoid any possible volatile reverse flow.

The oxygen carrier is decomposed in the fuel reactor, evolving gaseous oxygen to the surroundings. The oxygen burns the volatiles and char proceeding from coal pyrolysis in the fuel reactor. Reduced oxygen carrier particles overflowed into the air reactor through a U-shaped fluidized bed loop seal (2) with $30 \mathrm{~mm}$ of inner diameter. A $\mathrm{N}_{2}$ flow of $60 \mathrm{~L}_{\mathrm{N}} / \mathrm{h}$ was introduced in the loop seal. Preliminary experiments were carried out to observe the distribution of gas fed in to the loop seal. In the experimental conditions used in this work, the gas in the loop-seal was distributed approximated at $50 \%$ in each reactor (air and fuel reactor).

The oxidation of the carrier took place in the air reactor (3), being a bubbling fluidized bed with $80 \mathrm{~mm}$ of inner diameter and $100 \mathrm{~mm}$ bed height, and followed by a riser (4) with $30 \mathrm{~mm}$ of inner diameter. The air flow was $1740 \mathrm{~L}_{\mathrm{N}} / \mathrm{h}\left(\mathrm{u}_{\mathrm{g}}=0.40 \mathrm{~m} / \mathrm{s}\right)$. In addition, a secondary air flow $\left(240 \mathrm{~L}_{\mathrm{N}} / \mathrm{h}\right)$ was introduced at the top of the bubbling bed to help particle entrainment through a riser. $\mathrm{N}_{2}$ and unreacted $\mathrm{O}_{2}$ left the air reactor passing through a high-efficiency cyclone (5) and a filter before the stack. The oxidized solid particles recovered by the cyclone were sent to a solids reservoir (7), setting the oxygen carrier ready to start a new cycle. The regenerated oxygen carrier particles returned to the fuel reactor by gravity from the solids reservoir through a solids valve (8) which controls the flow rates of solids entering to the fuel reactor. A diverting solids valve (6) located below the cyclone allowed the measurement of the solids flow rates at any time. Therefore, this design allows us to control and to measure the solids circulation flow 
rate between both reactors. The ash particles from char combustion were not recovered by the cyclone and were collected in a filter down-stream. Thus, ash particles were not accumulated in the system. The ashes recovered in the filter closed the mass balance difference above $80 \%$ with regard to the amount of ash fed to the system. Further investigation on oxygen carrier extracted from the diverting valve (6) showed no presence of ash particles, confirming that ashes are not accumulated in the system. Finally, it is worthy of consideration that leakage of gas between both reactors was avoided by the presence of the U-shaped loop seal (2) and the solids reservoir (7). Thus, the presence of oxygen in the fuel reactor solely came from oxygen released by reaction (1).

The total oxygen carrier inventory in the system was around $2.0 \mathrm{~kg}$, being about $0.5-0.6$ $\mathrm{kg}$ in the fuel reactor. The amount of solids in the fuel reactor was calculated from pressure drop measurements in the reactor for each test.

$\mathrm{CO}_{2}, \mathrm{CO}, \mathrm{H}_{2}, \mathrm{CH}_{4}$, and $\mathrm{O}_{2}$ were continuously analyzed at the outlet stream from fuel reactor, whereas $\mathrm{CO}_{2}, \mathrm{CO}$ and $\mathrm{O}_{2}$ were analyzed from the flue gases of the air reactor. Non-dispersive infrared (NDIR) analyzers (Maihak S710/UNOR) were used for CO, $\mathrm{CO}_{2}$, and $\mathrm{CH}_{4}$ concentration determination; a paramagnetic analyzer (Maihak S710/OXOR-P) was used to determine $\mathrm{O}_{2}$ concentration; and a thermal conductivity detector (Maihak S710/THERMOR) was used for $\mathrm{H}_{2}$ concentration determination. In some selected experiments, the tar amount present in fuel reactor product gas was determined following the tar protocol (Simell et al., 2000), as well as higher $\mathrm{C}_{2}, \mathrm{C}_{3}$ and $\mathrm{C}_{4}$ hydrocarbons were analyzed off-line by a gas chromatograph (HP5890 Series II).

Because of heat losses, the system is not auto-thermal and it is heated up by means of various independent ovens to get independent temperature control of the air reactor, fuel reactor, and freeboard above the bed in the fuel reactor. During operation, temperatures in the bed and freeboard of the fuel reactor, air reactor bed and riser were monitored as well as the pressure drops in important locations of the system, such as the fuel reactor bed, the air reactor bed and the loop seal. The temperature in the fuel reactor was varied from 900 to $950{ }^{\circ} \mathrm{C}$, whereas the freeboard temperature was $900{ }^{\circ} \mathrm{C}$. The temperature in the air reactor was maintained at $900{ }^{\circ} \mathrm{C}$.

In Table 3, a resume of the operational variables used in this work for all coals is shown. The solids circulation rate was maintained at a mean value of 3-4 kg/h, whereas the coal feeding rate was varied from 0.08 to $0.13 \mathrm{~kg} / \mathrm{h}$ depending on the coal type. The oxygen carrier to fuel ratio, $\phi$, was around 1.0-1.2. The oxygen carrier to fuel ratio was 
defined as the ratio of the oxygen transported by the oxygen carrier to the oxygen demanded by coal for complete combustion. A value of $\phi=1$ corresponds to the stoichiometric flow of $\mathrm{CuO}$ needed to fully convert coal to $\mathrm{CO}_{2}$ and $\mathrm{H}_{2} \mathrm{O}$, being $\mathrm{CuO}$ reduced to $\mathrm{Cu}_{2} \mathrm{O}$. Thus, $\phi$ was calculated with the following equation:

$$
\phi=\frac{R_{\mathrm{OC}} \dot{m}_{\mathrm{OC}}}{\Omega_{\text {coal }} \dot{m}_{\text {coal }}}
$$

$\dot{\mathrm{m}}_{\mathrm{OC}}$ being the solids circulation flow rate in the completely oxidized state and $\dot{\mathrm{m}}_{\text {coal }}$ the mass-based flow of coal fed in to the reactor. $\Omega_{\text {coal }}$ is the stoichiometric $\mathrm{kg}$ of oxygen to convert $1 \mathrm{~kg}$ of coal to $\mathrm{CO}_{2}$ and $\mathrm{H}_{2} \mathrm{O}$. This value was calculated from the proximate and ultimate analysis of coal, see Table 2, by using the following equation:

$$
\Omega_{\text {coal }}=\left(\frac{f_{\mathrm{C}}}{M_{\mathrm{C}}}+0.25 \frac{f_{\mathrm{H}}}{M_{\mathrm{H}}}+0.5 \frac{f_{\mathrm{N}}}{M_{\mathrm{N}}}+\frac{f_{\mathrm{S}}}{M_{\mathrm{S}}}-\frac{f_{\mathrm{O}}}{M_{\mathrm{O}_{2}}}\right) \cdot M_{\mathrm{O}_{2}}
$$

$f_{\mathrm{i}}$ being the mass fraction of the element $\mathrm{i}$ in coal.

Air flow into the air reactor was maintained constant for all tests, always remaining in excess over the stoichiometric oxygen demanded by the fuel. The air excess ratio, $\lambda$, was defined in equation (7), and the values for the experimental work were always above 1, and are shown in Table 3.

$$
\lambda=\frac{\text { Oxygen flow }}{\text { Oxygen demanded }}=\frac{0.21 F_{\text {air }} M_{\mathrm{O}_{2}}}{\Omega_{\text {coal }} \dot{m}_{\text {coal }}}
$$

\subsection{Data evaluation}

Char reactivity was obtained in TGA tests from the weight variations during reaction with air as a function of time. The char conversion was calculated as:

$$
X_{\text {char }}=\frac{m_{0}-m}{m_{0}-m_{\text {ash }}}
$$

being $m$ the sample mass at each time, $m_{0}$ the char sample mass fully devolatilized and $m_{\text {ash }}$ the ash remaining mass in the char after reaction.

In the continuous CLOU unit, to analyze the confidence of the results, a mass balance to oxygen and carbon was carried out using the measurements of the gas stream coming from the air and fuel reactors. The product gas flow in dry basis in the fuel reactor, $F_{\text {outFR, was calculated as }}$

$$
F_{\text {outFR }}=\frac{F_{\text {inFR }}}{1-\left(y_{\mathrm{CO}_{2}, \text { outFR }}+y_{\mathrm{CO}, \text { outFR }}+y_{\mathrm{H}_{2}, \text { outFR }}+y_{\mathrm{CH}_{4}, \text { outFR }}+y_{\mathrm{O}_{2}, \text { outFR }}\right)}
$$


$F_{\text {inFR }}$ being the inlet flow to the fuel reactor, i.e. the sum of $\mathrm{N}_{2}$ for fluidizing, $\mathrm{N}_{2}$ from loop seal and $\mathrm{N}_{2}$ from the screw-feeder, and $y_{i, \text { outFR }}$ the $\mathrm{i}$ gas concentration exiting from the fuel reactor in dry basis.

The outlet gas flow from air reactor, $F_{\text {outAR, }}$ was calculated through the introduced $\mathrm{N}_{2}$.

$$
F_{\text {outAR }}=\frac{F_{\mathrm{N}_{2}, \text { inAR }}}{1-\left(y_{\mathrm{O}_{2}, \text { out } A \mathrm{R}}+y_{\mathrm{CO}_{2}, \text { out } A R}\right)}
$$

Thus, the exiting flows of $\mathrm{O}_{2}$ and $\mathrm{CO}_{2}$ from the air and fuel reactors can be easily calculated using the actual concentration of each gas $i$.

$$
F_{\mathrm{i}, \text { out }}=y_{\mathrm{i}, \text { out }} F_{\text {out }}
$$

Notice that nitrogen is used as fluidizing agent in the fuel reactor during experimental work, thus $\mathrm{CO}_{2}$ comes uniquely from the coal combustion. .

With the gas flows, a mass balance to carbon and oxygen was done as:

$$
\begin{gathered}
f_{\mathrm{C}} \cdot \dot{m}_{\text {coal }}=M_{\mathrm{C}}\left(F_{\mathrm{CO}_{2}, \text { outFR }}+F_{\mathrm{CO}, \text { outFR }}+F_{\mathrm{CH}_{4}, \text { outFR }}+F_{\mathrm{CO}_{2}, \text { outAR }}\right) \\
M_{\mathrm{O}_{2}}\left(F_{\mathrm{CO}_{2}, \text { outFR }}+F_{\mathrm{O}_{2}, \text { outFR }}+0.5 F_{\mathrm{CO}, \text { outFR }}+0.5 F_{\mathrm{H}_{2} \mathrm{O}, \text { outFR }}\right)_{\text {outFR }}-\left(\frac{f_{\mathrm{H}_{2} \mathrm{O}}}{M_{\mathrm{H}_{2} \mathrm{O}}}+\frac{f_{\mathrm{O}}}{M_{\mathrm{O}}}\right) \dot{m}_{\text {coal }}= \\
=M_{\mathrm{O}_{2}}\left[F_{\mathrm{O}_{2}, \text { inAR }}-\left(F_{\mathrm{O}_{2}, \text { outAR }}+F_{\mathrm{CO}_{2}, \text { outAR }}+0.5 F_{\mathrm{CO}, \text { outFR }}\right)\right]
\end{gathered}
$$

The water concentration was not measured. However, to consider the oxygen exiting with $\mathrm{H}_{2} \mathrm{O}$ coming from oxidation of hydrogen in the coal, it was assumed that water came both from humidity and hydrogen content in coal.

$$
F_{\mathrm{H}_{2} \mathrm{O}, \text { outFR }}=\left(0.5 \frac{f_{\mathrm{H}}}{M_{\mathrm{H}}}+\frac{f_{\mathrm{H}_{2} \mathrm{O}}}{M_{\mathrm{H}_{2} \mathrm{O}}}\right) \dot{m}_{\text {coal }}
$$

The evaluation of the CLOU performance with different coals was carried out by studying the effect of the operational variables on the carbon capture efficiency, the char conversion and the combustion efficiency in the fuel reactor.

The carbon capture efficiency, $\eta_{\mathrm{CC}}$, was defined as the fraction of carbon present in the coal which is at the outlet of fuel reactor. This is the real carbon captured in the CLOU system, as the remaining carbon exit as $\mathrm{CO}_{2}$ exiting together with nitrogen at the air reactor outlet.

$$
\eta_{\mathrm{CC}}=1-\frac{F_{\mathrm{CO}_{2}, \text { outAR }}}{F_{\mathrm{CO}_{2}, \text { outFR }}+F_{\mathrm{CO}, \text { outFR }}+F_{\mathrm{CH}_{4}, \text { outFR }}+F_{\mathrm{CO}_{2}, \text { outAR }}}
$$

The carbon capture efficiency depends on the conversion of char in the fuel reactor, $X_{\text {char }}$ Its value was calculated considering that the carbon contained in the fuel reactor 
comes from the carbon in volatiles and carbon in char converted. Thus, the carbon from char was the exiting carbon minus the flow of carbon in volatiles, $F_{\mathrm{C} \text {,vol }}$ :

$$
X_{\text {char }}=1-\frac{F_{\mathrm{CO}_{2} \text {,outAR }}}{F_{\mathrm{CO}_{2}, \text { outFR }}+F_{\mathrm{CO}, \text { outFR }}+F_{\mathrm{CH}_{4}, \text { outFR }}+F_{\mathrm{CO}_{2} \text {,outAR }}-F_{\mathrm{C}, \text { vol }}}
$$

The molar flow of carbon contained in the volatile matter was calculated as

$$
F_{\mathrm{C}, \text { vol }}=\frac{\left(f_{\mathrm{C}}-f_{\mathrm{C}, \mathrm{fix}}\right) \dot{m}_{\text {coal }}}{M_{\mathrm{C}}}
$$

$f_{\mathrm{C} \text {,fix }}$ being the fixed carbon given by coal analysis, see Table 2 . Eq. (17) assumes that the volatiles evolved in the fuel reactor are the same as in a proximate analysis measurement.

The conversion of char in the fuel reactor was related to the temperature and the mean residence time of solids in the fuel reactor, $\tau_{\mathrm{FR}}$, which is calculated by the following equation:

$\tau_{\mathrm{FR}}=\frac{m_{\mathrm{s}, \mathrm{FR}}}{\dot{m}_{\mathrm{OC}}}$

$m_{\mathrm{s}, \mathrm{FR}}$ being the mass of solids in the fuel reactor and $\dot{m}_{\mathrm{OC}}$ the solids circulation rate between the air and fuel reactors.

The fractional conversion rate of the char, $\left(-r_{\mathrm{C}}\right)$, can be calculated from the values of the char conversion in the fuel reactor and the mean residence time of char particles in this reactor, $\tau_{\text {char. }}$ The fractional conversion rate of char was calculated as follow:

$$
\left(-r_{\mathrm{c}}\right)=\frac{X_{\text {char }}}{\tau_{\text {char }}}
$$

$\tau_{\text {char }}$ is related to the mean residence time of solids in the fuel reactor with the following equation:

$$
\tau_{\text {char }}=\tau_{\mathrm{FR}} \cdot\left(1-X_{\text {char }}\right)
$$

Finally, the combustion efficiency in the fuel reactor, $\eta_{\text {comb,FR }}$, evaluates the combustion degree only to the fraction of coal converted in the fuel reactor. The combustion efficiency in the fuel reactor was calculated through the quotient between the oxygen required to fully burn unconverted gases $\left(\mathrm{CH}_{4}, \mathrm{CO}\right.$ and $\left.\mathrm{H}_{2}\right)$ and the oxygen demanded for full combustion of the coal converted in the fuel reactor. Therefore, the combustion efficiency in the fuel reactor was calculated as: 
$\eta_{\text {comb }, \mathrm{FR}}=1-\frac{4 \mathrm{~F}_{\mathrm{CH}_{4}, \text { outFR }}+\mathrm{F}_{\mathrm{CO}, \text { outFR }}+\mathrm{F}_{\mathrm{H}_{2}, \text { outFR }}}{2 \Omega_{\text {coal }} \dot{\mathrm{m}}_{\text {coal }}-2 \mathrm{~F}_{\mathrm{CO}_{2}, \text { outAR }}}$

\section{Results}

To investigate the performance of the CLOU system for the combustion of different coals, several tests under continuous operation were carried out in the ICB-CSIC-s1 experimental rig. The $\mathrm{Cu} 60 \mathrm{MgAl}$ material was used as oxygen carrier. The effect of the coal rank and the fuel reactor temperature on the combustion efficiency and carbon capture efficiency was investigated. Thus, the fuel reactor temperature was varied from $900{ }^{\circ} \mathrm{C}$ to $950{ }^{\circ} \mathrm{C}$. A total of $40 \mathrm{~h}$ of operation were carried out. Similarly to that found in a previous work (Adánez-Rubio et al., 2012b), both reactivity and oxygen transport capacity of solids were maintained constant during the experimental work.

The gas composition of the exit gases of fuel and air reactor was determined for every experimental condition. As example, Fig. 3 shows the concentration of gases (dry basis) measured as a function of the operating time for experiments carried out with lignite. Several temperatures in the fuel reactor was tested, and at least 60 min was operated at constant temperature.

When temperature was varied, a transition period appeared and stable combustion was reached usually in less than $10 \mathrm{~min}$. At steady state, the gas outlet concentration and temperature were maintained uniform during the whole combustion time. The mass balances for carbon and oxygen, see Eqs. (12) and (13), were found to be accurate. Thus, the loss of carbon by elutriation of char particles from the fuel reactor or carbon not recovered by cyclone was negligible regarding the carbon balance in the system. Moreover, when the oxygen transferred from the oxygen carrier to the fuel was equal to the oxygen transferred from the air to the oxygen carrier, the steady state was reached. In all cases, no $\mathrm{CH}_{4}, \mathrm{CO}$ or $\mathrm{H}_{2}$ were detected in the gases exiting from the fuel reactor. The possible presence of tars or light hydrocarbons was also analyzed. In addition, in the experiments done at the lowest temperature for all the coals, tar measurements in the fuel reactor were done using a tar protocol. The results showed that there were not tars in the fuel reactor outlet flow, that is, no hydrocarbons heavier than $\mathrm{C}_{5}$. Also in these experiments, gas from the outlet stream of fuel reactor was collected in bags and analysed with a gas chromatograph. The analysis proved that there were no $\mathrm{C}_{2}-\mathrm{C}_{4}$ hydrocarbons in the gases. Thus, $\mathrm{CO}_{2}, \mathrm{H}_{2} \mathrm{O}$ and $\mathrm{O}_{2}$ were the only gases, together with 
$\mathrm{N}_{2}$ introduced as fluidizing gas. Also, small fractions of $\mathrm{SO}_{2}$ and $\mathrm{NO}$ were present in the gases coming from sulphur and nitrogen present in the coal. However, these components were not evaluated in this work.

Therefore, it was found that volatiles were fully converted into $\mathrm{CO}_{2}$ and $\mathrm{H}_{2} \mathrm{O}$ in the fuel reactor by reaction with the oxygen released from the $\mathrm{CuO}$ decomposition. In addition, the oxygen release rate was high enough to supply an excess of gaseous oxygen $\left(\mathrm{O}_{2}\right)$ exiting together with the combustion gases. Oxygen concentration was close to thermodynamic equilibrium for each reactor temperature, being the oxygen concentration at equilibrium conditions $1.7 \%$ at $910^{\circ} \mathrm{C}, 2.4 \%$ at $925^{\circ} \mathrm{C}, 3.0 \%$ at $935^{\circ} \mathrm{C}$ and $4.2 \%$ at $950^{\circ} \mathrm{C}$. As temperature was increased, more $\mathrm{O}_{2}$ is released from the fuel reactor according to equilibrium of $\mathrm{CuO}$ decomposition. On the other hand, the $\mathrm{O}_{2}$ concentration at the outlet of the air reactor slightly decreased with temperature due to the oxygen carrier comes more reduced from the fuel reactor because more oxygen was released in the fuel reactor. Similar results were found with the other fuels.

Fig. 4(a) shows the combustion and carbon capture efficiency obtained for different coals as a function of the fuel reactor temperature. Complete combustion in the fuel reactor of coal to $\mathrm{CO}_{2}$ and $\mathrm{H}_{2} \mathrm{O}$ was found for all the operating conditions and coals. Note the low solids inventory used in the CLOU system (see Table 3) compared to CLC with coal, where about $1800 \mathrm{~kg} / \mathrm{MW}_{\text {th }}$ was necessary to obtain a combustion efficiency of $96 \%$ (Cuadrat et al., 2011). However, the type of coal affected to the carbon capture efficiency. The carbon capture efficiency decreased in the order Lignite $>$ Medium Volatile Bituminous $>$ Low Volatile Bituminous $>$ Anthracite. For all coals, $\mathrm{CO}_{2}$ capture increased with temperature, being this effect more relevant for coals with low volatile matter content as Anthracite and LV Bituminous coal. Similar carbon capture efficiencies were obtained for Lignite and Medium Volatile Bituminous coal at temperatures above $940{ }^{\circ} \mathrm{C}$. In these cases, the carbon capture efficiency was above $99 \%$, but lower values were obtained for Low Volatile Bituminous coal $(90 \%)$ or Anthracite (83\%). This result clearly indicates the need of a carbon separation system when low reactive coals are used, to return unconverted char to the fuel reactor. This system is similar to the proposed for CLC with solid fuels (Cao and Pan, 2006). In this way it is possible to increase the char conversion and to reduce the amount of char transferred to the air reactor. The need of a carbon separation system will depend mainly on the coal reactivity in combustion with oxygen. 
$\mathrm{CO}_{2}$ capture efficiencies are dependent on the carbon transferred from the fuel to the air reactor. As the all carbon in volatiles were captured, the carbon capture depends on the unconverted char in the fuel reactor, i.e. the char conversion, which in a CLOU or a CLC system can be affected by the reactor temperature and the solids circulation flow rate (Cuadrat et al., 2012d). Nevertheless, the solids flow rate was maintained constant for all the tests. Fig. 4(b) shows the char conversion as a function of the fuel reactor temperature for different coals. Similar trends to that found for the $\mathrm{CO}_{2}$ capture efficiency were found for different coals. Char conversions increased when the temperature increased for all coals and the increase was more effective for low rank coals.

The differences observed in char conversion among the different fuel must be related with the intrinsic combustion reactivity of the coals. Thus, reactivity of the coal chars was determined in TGA. Fig. 5 shows the char conversion versus time obtained in TGA using air at $500{ }^{\circ} \mathrm{C}$ for the different fuels used in this study. It can be observed that Lignite char is the most reactive which is attributed to the low amount of fixed carbon and high amount of oxygen. The reactivity of LV Bituminous and Anthracite are very similar and lower than MV Bituminous and Lignite. Thus, chars from LV Bituminous coal and Anthracite need elevated reaction times to reach a high conversion. Besides, the reactivity of the different fuels in TGA explains the tendency of the $\mathrm{CO}_{2}$ capture efficiency and the char conversion measured in the continuous CLOU unit. Thus, the highest $\mathrm{CO}_{2}$ capture efficiency was measured with the most reactive fuel, i.e. the Lignite. However, the TGA reactivity for Anthracite and LV Bituminous char were similar, and the char conversion measured in the continuous CLOU unit of these coals were different.

Fractional conversion rate of char per unit of carbon mass in char can be used to carry out a comparison between the different coals, because char conversion in the fuel reactor depends directly of this rate. Fig. 6 shows the fractional conversion rate of char as a function of temperature calculated using Eq. (19) for the four coals used in the CLOU unit. As expected, the fractional conversion rate of char increases with temperature. The differences between fractional conversion rates showed in Fig. 6 for the different fuels are lower than the difference in reactivity measured in the TGA. It is necessary to consider that at the operating conditions used in the CLOU unit, the reaction rates are in a reaction regime II for porous solids (Walker et al., 1968), that is, the effect of char reactivity is smoothed by the mixed control of the diffusion and kinetic rates. 


\section{Discussion}

With the results obtained in the continuous CLOU unit, an optimization of the CLOU process has been carried out to maximize the $\mathrm{CO}_{2}$ capture efficiency with the minimum solid inventory. Thus, the carbon capture efficiency was analyzed as a function of the fractional conversion rate of char of the different coals (Cuadrat et al., 2012b). The effect of using a carbon separation system is also analyzed in this section.

As carbon capture efficiency depends on the char conversion in the fuel reactor, a carbon separation system can be used to improve the char conversion and carbon capture in the system. This system allows the separation of char from the oxygen carrier by fluidized bed selective entrainment. In this way the char is transported to the fuel reactor to improve the char conversion, whereas oxygen carrier particles sent to the air reactor.

Considering a carbon separation system, char conversion can be calculated as a function of the carbon separation system efficiency as follows (Cuadrat et al., 2012b):

$$
X_{\text {char }}=1-\frac{\dot{m}_{\mathrm{oc}}\left(1-\eta_{\mathrm{cSs}}\right)}{\left(-r_{\mathrm{c}}\right) \cdot m_{\mathrm{s}, \mathrm{FR}}+\dot{m}_{\mathrm{oc}}\left(1-\eta_{\mathrm{cSs}}\right)}
$$

where $\dot{m}_{\mathrm{s}}$ is the oxygen carrier flow rate, $\eta_{\mathrm{CCS}}$ is the carbon separation system efficiency, $\left(-r_{\mathrm{C}}\right)$ the fractional conversion rate of char and $m_{\mathrm{s}, \mathrm{FR}}$ the mass of oxygen carrier in the fuel reactor. The carbon capture efficiency is related to the char conversion with the following equation:

$$
\eta_{\mathrm{CC}}=\frac{f_{\mathrm{C}, \mathrm{vol}}}{f_{\mathrm{C}}}+\frac{f_{\mathrm{C}, \text { char }}}{f_{\mathrm{C}}} \cdot X_{\text {char }}=\frac{f_{\mathrm{C}}-f_{\mathrm{C}, \mathrm{fix}}}{f_{\mathrm{C}}}+\frac{f_{\mathrm{C}, \text { fix }}}{f_{\mathrm{C}}} X_{\text {char }}
$$

Using Eq. 22 and 23, it is possible to analyze the effect of the oxygen carrier inventory and the efficiency of carbon separation system on char conversion and carbon capture efficiency in the system, once the value of $\left(-r_{C}\right)$ is known.

Figs. 7(a), (b) and (c) show the char conversion as a function of the fuel reactor inventory for Lignite when a carbon separation system with different efficiency $\left(\eta_{\text {CCS }}=\right.$ 0, 50 and 90\%) is considered at 909 (a), 935 (b) and $950{ }^{\circ} \mathrm{C}$ (c). In this analysis, the residence time of solids was maximized by operating at a value of the oxygen carrier to fuel ratio, $\phi=1.1$ (Cuadrat et al., 2012c). Namely, the solid circulation flow rate per $\mathrm{MW}_{\text {th }}$ of fuel was fixed for every coal. As it can be seen in Fig. 7(a), if the carbon 
separation system efficiency $\left(\eta_{\mathrm{CCS}}\right)$ is given, the char conversion increases with the oxygen carrier inventory due to the increase of the residence time of solids in the fuel reactor. For the same reason, if $\eta_{C C S}$ increases more char returns to the fuel reactor increasing its residence time. As a consequence, the char conversion increases with $\eta_{\text {CCS }}$. The effect of carbon separation system was very high especially at the lower temperatures and lower oxygen carrier inventories in the fuel reactor.

It is possible to calculate the carbon capture efficiencies in the CLOU process by using Eq. (23). Fig. 8(a), (b) and (c) show the carbon capture efficiency as a function of the fuel reactor inventory for Lignite when a carbon separation system with different efficiencies $\left(\eta_{\mathrm{CCS}}=0,50\right.$ and $\left.90 \%\right)$ is considered at 909 (a), 935 (b) and $950{ }^{\circ} \mathrm{C}$ (c). Carbon capture efficiency increases with the fuel reactor inventory for a fixed carbon separation system efficiency, due to the increase of the char conversion. As can be seen in the figures, the effect of carbon separation system was very high especially at the lower temperatures and lower oxygen carrier inventories in the fuel reactor.

Same trends were found for the different coals used in this work although values were dependent on coal reactivity which was related with the coal rank. With low reactivity coals higher oxygen carrier inventories were needed to obtain the same carbon capture efficiency using a carbon separation system with the same efficiency, $\eta_{\text {CCs }}$.

Fig. 9 shows the minimum fuel reactor inventory necessary to reach a carbon capture efficiency of $95 \%$ as a function of the temperature a carbon separation system with $\eta_{\text {CSS }}$ $=90 \%$ was also included with all different coals. Important differences were found depending on the coal rank. Lignite and MV Bituminous, have a high char conversion rate and need very low fuel reactor inventories, with values of 45 and $85 \mathrm{~kg} / \mathrm{MW}_{\text {th }}$ respectively to reach $95 \%$ carbon capture efficiency at $925{ }^{\circ} \mathrm{C}$ respectively. At these conditions, the residence time of solids in the fuel reactor is 31 and $58 \mathrm{~s}$, respectively. As opposite, for anthracite higher fuel reactor inventories are needed to reach high values of carbon capture efficiency, near $490 \mathrm{~kg} / \mathrm{MW}_{\text {th }}$ at $925^{\circ} \mathrm{C}$, with a residence time of $365 \mathrm{~s}$. However, these inventories are much lower than those found to burn anthracite in the CLC process using ilmenite (Cuadrat et al., 2012b and 2012c) as $1800 \mathrm{~kg} / \mathrm{MW}_{\text {th }}$ are needed. Moreover, the inventories needed for the different fuels showed an important decrease with temperature indicating the need of fuel reactor temperatures as higher as possible, especially for Anthracite. 
These inventories are calculated to reach high char conversion values. However, it must be taken into account the oxygen carrier reactivity. In a previous work using this oxygen carrier, Adánez-Rubio et al. (2012a) defined three different regions of combustion behaviour depending on the solid inventory. The minimum oxygen carrier inventory necessary to reach complete combustion to $\mathrm{CO}_{2}$ and $\mathrm{H}_{2} \mathrm{O}$ (Region I) was $58 \mathrm{~kg} / \mathrm{MW}_{\text {th }}$ at $955^{\circ} \mathrm{C}$. Therefore, a solid inventory of $35 \mathrm{~kg} / \mathrm{MW}_{\text {th }}$ (using Lignite at $950{ }^{\circ} \mathrm{C}$, see Fig. 9) represents operation in Region III, where incomplete combustion occurs. This fact indicates that in the case of highly reactive coals, e.g. Lignite or Medium Volatiles Bituminous coals, the solids inventory will be defined by the amount of solids necessary to reach complete combustion rather than to reach high char conversion values In other cases, i.e. low reactive coals or absence of a carbon separation system, the solids inventory in the fuel reactor will come defined to have solids residence time high enough to convert the char. In this case, the absence of unburnt products would be guaranteed even if lower solid inventories were used. At these conditions (Region I defined by Adánez-Rubio et al. (2012a)), complete combustion is reached, although some oxygen at equilibrium conditions will be also present. This oxygen could to limit the fuel reactor temperature if the oxygen concentration in the $\mathrm{CO}_{2}$ stream should minimized, because this oxygen must be separated from $\mathrm{CO}_{2}$ before its transport and storage (Allam et al., 2005)

\section{Conclusions}

The performance of the CLOU process for combustion of coals of different rank with a $\mathrm{Cu}$-based oxygen carrier $(\mathrm{Cu} 60 \mathrm{MgAl})$ prepared by spray-drying was determined in a continuously operated unit.

With all the coals used, unburnt compounds were not present in the fuel reactor outlet. $\mathrm{CO}_{2}, \mathrm{H}_{2} \mathrm{O}$ and $\mathrm{O}_{2}$ were the only products present at the fuel reactor outlet. Very high carbon capture efficiencies were obtained for Lignite and MV Bituminous coals, reaching values of $99 \%$ with Lignite at $950{ }^{\circ} \mathrm{C}$. The carbon capture efficiency increased with fuel reactor temperature and this increase was more relevant for Anthracite and LV Bituminous.

The coal rank showed an important effect on the carbon capture efficiency. For low reactivity coals it is necessary the use of a carbon separation system to reach a $\mathrm{CO}_{2}$ capture efficiencies higher than $95 \%$. 
The analysis of the experimental results was used to evaluate the performance of the CLOU system when a carbon separation system is included using different coal rank. It was found very low solid inventories for all the different coal rank used. For example, at $925{ }^{\circ} \mathrm{C}$ the solid inventory needed to reach a $95 \%$ of $\mathrm{CO}_{2}$ capture efficiency with a carbon separation system of $90 \%$ of efficiency is $45 \mathrm{~kg} / \mathrm{MW}_{\text {th }}$ using Lignite, 85 $\mathrm{kg} / \mathrm{MW}_{\text {th }}$ using MV Bituminous, $140 \mathrm{~kg} / \mathrm{MW}_{\text {th }}$ using LV Bituminous and $490 \mathrm{~kg} / \mathrm{MW}_{\text {th }}$ using Anthracite. The residence times corresponding to these inventory values are 31 , 58,140 and $365 \mathrm{~s}$, respectively.

\section{ACKNOWLEDGEMENT}

This work was partially supported by the European Commission, under the RFCS program (ECLAIR Project, Contract RFCP-CT-2008-0008), ALSTOM Power Boilers (France) and by the Spanish Ministry of Science and Innovation (PN, ENE2010-19550). I. Adánez-Rubio thanks CSIC for the JAE fellowship co-fund by the European Social Fund. 


\section{NOTATION}

Symbols

$F_{\mathrm{i}} \quad$ Molar flow of compound i $(\mathrm{mol} / \mathrm{s})$

$f_{\mathrm{C}} \quad$ Mass fraction of carbon in coal (-)

$f_{\text {C,fix }} \quad$ Mass fraction of fix carbon in coal (-)

$f_{\mathrm{C}, \mathrm{vol}} \quad$ Mass fraction of carbon in volatiles (-)

$f_{\mathrm{i}} \quad$ Mass fraction in coal of element or compound i (-)

$M_{\mathrm{i}} \quad$ Atomic or molecular weigh of i elements or compound $(\mathrm{kg} / \mathrm{mol})$

$m \quad$ Mass of the sample at each time in TGA $(\mathrm{kg})$

$m_{0} \quad$ Initial mass of char in TGA $(\mathrm{kg})$

$m_{\text {ash }} \quad$ Mass of ash remaining after full combustion in TGA $(\mathrm{kg})$

$\dot{m}_{\text {coal }} \quad$ Mass-based flow of coal fed-in to the fuel reactor $(\mathrm{kg} / \mathrm{s})$

$\dot{m}_{\mathrm{OC}} \quad$ Solids circulation rate $(\mathrm{kg} / \mathrm{s})$

$m_{\mathrm{ox}} \quad$ Mass of the oxygen carrier sample fully oxidized $(\mathrm{kg})$

$m_{\text {red }} \quad$ Mass of the oxygen carrier sample fully reduced $(\mathrm{kg})$

$m_{\mathrm{s}, \mathrm{FR}} \quad$ Mass of solids in the fuel reactor $(\mathrm{kg})$

$R_{\mathrm{OC}} \quad$ Oxygen transport capability (-)

$\left(-r_{\mathrm{C}}\right) \quad$ Fractional conversion rate of the char $\left(\mathrm{s}^{-1}\right)$

$\tau_{\text {char }} \quad$ Mean residence time of char particles in the fuel reactor (s)

$\tau_{\mathrm{FR}} \quad$ Mean residence time of solids in the fuel reactor (s)

$X_{\text {char }} \quad$ Char conversion (-)

$\mathrm{y}_{\mathrm{i}, \text { outFR }} \quad$ Molar fraction of the gas i exiting from the fuel reactor (-)

$\mathrm{y}_{\mathrm{i}, \text { outAR }} \quad$ Molar fraction of the gas i exiting from the air reactor (-)

Greek letters

$\eta_{\mathrm{CC}} \quad$ Carbon capture efficiency (-)

$\eta_{\text {comb,FR }} \quad$ Combustion efficiency in the fuel reactor (-)

$\eta_{\text {Css }} \quad$ Efficiency of the carbon separation system (-)

$\lambda \quad$ Air excess ratio (-)

$\phi \quad$ Oxygen carrier to fuel ratio (-) 
$\Omega_{\text {coal }} \quad$ Stoichiometric mass of $\mathrm{O}_{2}$ to convert $1 \mathrm{~kg}$ of coal $(\mathrm{kg} / \mathrm{kg})$

Subscripts

$\begin{array}{ll}\text { AR } & \text { Air reactor } \\ \text { BET } & \text { Brunauer-Emmett-Teller } \\ \text { CLC } & \text { Chemical-Looping Combustion } \\ \text { CLOU } & \text { Chemical-Looping with Oxygen Uncoupling } \\ \text { FR } & \text { Fuel reactor } \\ \text { inAR } & \text { Inlet stream from air reactor } \\ \text { inFR } & \text { Inlet stream from fuel reactor } \\ \text { IPCC } & \text { Intergovernmental Panel on Climate Change } \\ \text { outAR } & \text { Outlet stream from air reactor } \\ \text { outFR } & \text { Outlet stream from fuel reactor } \\ \text { OC } & \text { Oxygen carrier } \\ \text { TGA } & \text { Thermogravimetric analyzer } \\ \text { XRD } & \text { X-ray diffractometer }\end{array}$




\section{REFERENCES}

Abad, A., Adánez-Rubio, I., Gayán, P., García-Labiano, F., de Diego, LF., Adánez, J., 2012. Demonstration of chemical-looping with oxygen uncoupling (CLOU) process in a $1.5 \mathrm{kWth}$ continuously operating unit using a $\mathrm{Cu}$-based oxygen-carrier. International Journal of Greenhouse Gas Control 6, 189-200.

Adánez, J., de Diego, L.F., García-Labiano, F., Abad A., Abanades, J.C., 2001. Determination of biomass char combustion reactivities for FBC apllications by a combined method. Ind. Eng. Chem. Res., 40 (20), 4317-4323.

Adánez, J., Gayán, P., Celaya, J., de Diego, L.F., García-Labiano, F., Abad, A., 2006. Chemical looping combustion in a $10 \mathrm{~kW}$ th prototype using a $\mathrm{CuO} / \mathrm{Al}_{2} \mathrm{O}_{3}$ oxygen carrier: effect of operating conditions on methane combustion. Ind. Eng. Chem. Res. 45(17), 75-80.

Adanez, J., Abad, A., Garcia-Labiano, F., Gayan, P., de Diego, L.F., 2012. Progress in Chemical-Looping Combustion and Reforming Technologies. Prog. Energy Comb. Sci. $38,215-282$.

Adánez-Rubio, I., Gayán, P., García-Labiano, F., de Diego, L.F., Adánez, J., Abad, A., 2011. Development of CuO-based oxygen carrier materials suitable for chemicallooping with oxygen uncoupling (CLOU). Energy Procedia 4, 417-424.

Adánez-Rubio, I., Gayán, P., Abad, A., de Diego, L.F., García-Labiano, F., Adánez, J., 2012a. Identification of Operational Regions in the Chemical-Looping with Oxygen Uncoupling (CLOU) Process with a Cu-based Oxygen-Carrier. Fuel, doi: 10.1016/j.fuel.2012.06.063.

Adánez-Rubio, I., Gayán, P., Abad, A., de Diego, L.F., García-Labiano, F., Adánez, J., 2012b. Evaluation of a Spray-Dried $\mathrm{CuO} / \mathrm{MgAl}_{2} \mathrm{O}_{4}$ Oxygen Carrier for the Chemical Looping with Oxygen Uncoupling Process. Energy Fuels 26(5), 3069-3081.

Allam, R., White, V., Ivens, N., Simmonds, M., 2005 The oxyfuel baseline: revamping heaters and boilers to oxyfiring by cryogenic air separation and flue gas recycle, in: Thomas D.C., Benson S.M., (Eds.), Carbon Dioxide Capture for Storage in Deep Geologic Formations - Results from the $\mathrm{CO}_{2}$ Capture Project. Elsevier, Oxford, vol. 1, chapter 26.

Azimi, G., Leion, H., Mattisson, T., Lyngfelt, A., 2011. Chemical-looping with oxygen uncoupling using combined Mn-Fe oxides, testing in batch fluidized bed. Energy Procedia 4, 370-377.

Berguerand, N., Lyngfelt, A., 2008. Design and operation of a $10 \mathrm{~kW}_{\text {th }}$ chemicallooping combustor for solid fuels - Testing with South African coal. Fuel 87, 27132726.

Berguerand, N., Lyngfelt, A., 2009. Chemical-Looping combustion of petroleum coke using ilmenite in a $10 \mathrm{kWth}$ unit-High-temperature operation. Energy Fuels 23, 57-68. 
Cao, Y., and Pan W.P., 2006. Investigation of chemical looping combustion by solid fuels. 1. Process analysis. Energy Fuels 20, 57-68.

Cuadrat, A., Abad, A., García-Labiano, F., Gayan, P., de Diego, L.F., Adánez, J.,2011. The use of ilmenite as oxygen-carrier in a $500 \mathrm{~W}($ th) Chemical-Looping Coal Combustion unit. Int J Greenhouse Gas Control 5, 1630-1642.

Cuadrat, A., Abad, A., García-Labiano, F., Gayán, P., de Diego, L.F., Adánez, J., 2012a. Relevance of the coal rank on the performance of the in-situ Gasification Chemical-Looping Combustion. Chem. Eng. J. 2012, doi: 10.1016/j.cej.2012.04.052.

Cuadrat, A., Abad, A., de Diego, L.F., García-Labiano, F., Gayán, P., Adánez, J.,2012b. Prompt considerations on the design of Chemical-Looping Combustion of coal from experimental tests. Fuel. doi:10.1016/j.fuel.2012.01.050.

Cuadrat, A., Abad, A., Gayán, P., de Diego, L.F., García-Labiano, F., Adánez, J.,2012c. Theoretical approach on the CLC performance with solid fuels: Optimizing the solids inventory. Fuel. doi:10.1016/j.fuel.2012.01.071.

Cuadrat, A., Abad, A., García-Labiano, F., Gayán, P., de Diego, L.F., Adánez, J., 2012d. Effect of operating conditions in Chemical-Looping Combustion of coal in a 500 $\mathrm{W}_{\text {th }}$ unit. Int. J. Greenhous Gas Control 6, 153-163.

de Diego, L. F., García-Labiano, F., Adánez, J., Gayán, P., Abad, A., Corbella, B. M, Palacios, J. M., 2004. Development of $\mathrm{Cu}$-based oxygen carriers for chemical-looping combustion. Fuel 83(13), 49-57.

Eyring, E., Konya, G., Lighty, J., Sahir, A., Sarofim, A., Whitty, K., 2011. Chemical looping with copper oxide as carrier and coal as fuel. Oil \& Gas Science and Technology- Revue IFP Nouvelles Technologies 2, 209-221.

Gayán, P., Adánez-Rubio, I., Abad, A., de Diego, L.F., García-Labiano, F., Adánez, J., 2012. Development of CuO-based oxygen-carrier materials suitable for ChemicalLooping with Oxygen Uncoupling (CLOU) process. Fuel 96, 226-238.

IPCC, 2005. IPCC special report on carbon dioxide capture and storage, in: B. Metz, O. Davidson, H.C. de Coninck, M. Loos and L.A. Meyer, Editors, Working group III of the intergovernmental panel on climate change, Cambridge University.

Kerr, H.R., 2005. In: Thomas DC, Benson SM, editors. Capture and Separation Technology Gaps and Priority Research Needs. Carbon Dioxide Capture for Storage in Deep Geologic Formations, Elsevier Science, Amsterdam, pp. 655-660.

Kolbitsch, P., Bolhàr-Nordenkampf, J., Pröll, T., Hofbauer, H., 2009. Comparison of two Ni-based oxygen carriers for chemical looping combustion of natural gas in 140 kW continuous looping operation. Ind. Eng. Chem. Res. 48(11), 42-47.

Kvamsdal, H.M., Jordal, K., Bolland, O., 2007. A quantitative comparison of gas turbine cycles with $\mathrm{CO}_{2}$ capture. Energy 32(1),10-24. 
Leion, H., Mattissson, T., Lyngfelt, A., 2007. The use of petroleum coke as fuel in chemical-looping combustion. Fuel 86, 1947-1958.

Leion, H., Larring, Y., Bakken, E., Bredesen, R., Mattissson, T., Lyngfelt, A., 2009a. Use of $\mathrm{CaMn}_{0.875} \mathrm{Ti}_{0.125} \mathrm{O}_{3}$ as oxygen carrier in chemical looping with oxygen uncoupling. Energy Fuels 23, 5276-5283.

Leion, H., Mattisson, T., Lyngfelt, A., 2009b. Using chemical-looping with oxygen uncoupling (CLOU) for combustion of six different solid fuels. Energy Procedia 1, 447-453.

Lewis, W.K., Gilliland, E.R., 1954. Production of pure carbon dioxide. Patent 2665972.

Linderholm, C., Mattisson, T., Lyngfelt, A., 2009. Long-term integrity testing of spraydried particles in a $10 \mathrm{~kW}$ chemical-looping combustor using natural gas as fuel. Fuel 88, 2083-2096.

Mattisson, T., Lyngfelt, A., Leion, H., 2009a. Chemical-looping oxygen uncoupling for combustion of solid fuels. Int J Greenhouse Gas Control 3, 11-19.

Mattisson, T., Leion, H., Lyngfelt, A., 2009b. Chemical-Looping with Oxygen Uncopling using $\mathrm{CuO} / \mathrm{ZrO}_{2}$ with petroleum coke. Fuel 88, 683-690.

Pröll, T., Mayer, K., Bolhàr-Nordenkampf, J., Kolbitsch, P., Mattisson, T., Lyngfelt, A., Hofbauer, H., 2009. Natural minerals as oxygen carriers for chemical looping combustion in a dual circulating fluidized bed system. Energy Procedia 1, 27-34.

Rydén, M., Lyngfelt, A., Mattisson, T., 2011a. $\mathrm{CaMn}_{0.875} \mathrm{Ti}_{0.125} \mathrm{O}_{3}$ as oxygen carrier for chemical oxygen combustion with oxygen uncoupling (CLOU) - Experiments in a continuously operating fluidized-bed reactor system. Int. J. Greenhouse Gas Control 5, 356-366.

Rydén, M., Lyngfelt, A., Mattisson, T., 2011b. Combined manganese/iron oxides as oxygen carrier for chemical looping combustion with oxygen uncoupling (CLOU) in a circulating fluidized bed reactor system. Energy Procedia 4, 341-348.

Ryu, H.-J., Jo, S.-H., Park, Y.Ch., Bae, D.-H., Kim, S.D., 2010. Long-term Operation Experience in a $50 \mathrm{~kW}_{\text {th }}$ Chemical Looping Combustor using Natural Gas and Syngas as Fuels. Proceedings from the $1^{\text {st }}$ International Conference on Chemical Looping, 1719 March 2010, Lyon (France).

Scott, S.A., Dennis, J.S., Hayhurst, A.N., Brown, T., 2006. In Situ Gasification of a Solid Fuel and $\mathrm{CO}_{2}$ Separation using Chemical Looping. AIChE J. 52, 3325-3328.

Shen, L., Wu, J., Xiao, J., Song, Q., Xiao, R., 2009. Chemical-Looping Combustion of Biomass in a $10 \mathrm{~kW}_{\text {th }}$ Reactor with Iron Oxide as an Oxygen Carrier. Energy \& Fuels 23, 2498-2505. 
Shulman, A., Cleverstam, E., Mattisson, T., Lyngfelt, A., 2009. Manganese/iron, manganese/nickel, and manganese/silicon oxides used in chemical looping with oxygen uncoupling (CLOU) for combustion of methane. Energy Fuels 23, 5269-5275.

Shulman, A., Cleverstam, E., Mattisson, T., Lyngfelt, A., 2011. Chemical-Looping with oxygen uncoupling using $\mathrm{Mn} / \mathrm{Mg}$-based oxygen carriers - Oxygen release and reactivity with methane. Fuel 90, 941-950.

Simell, P., Stahlberg, P., Kurkela E., Albretch J., Deutch S., Sjostrom K., 2000.

Provisional protocol for the sampling and analysis of tar and particulates in the gas from large-scale biomass gasifiers. Version 1998. Biomass and Bioenergy 18, 19-38.

Walker, P. L. Jr., Shelef, M., Anderson, R.A. 1968, Chemistry and Physics of Carbon 4, 287-380, Marcel Dekker, NY. 


\section{Caption of Tables}

Table 1. Properties of the oxygen carrier $\mathrm{Cu} 60 \mathrm{MgAl}$.

Table 2. Properties of coals used in this work.

Table 3. Operational conditions during experimental work in ICB-CSIC-s1 unit. 
Table 1. Properties of the oxygen carrier Cu60MgAl.

\begin{tabular}{ll}
\hline CuO content (wt.\%) & 60 \\
Oxygen transport capacity, $\mathrm{R}_{\mathrm{OC}}(\mathrm{wt} . \%)$ & 6 \\
Crushing strength (N) & 2.4 \\
Skeletal density $\left(\mathrm{kg} / \mathrm{m}^{3}\right)$ & 4600 \\
Porosity (\%) & 16.1 \\
Specific surface area, BET $\left(\mathrm{m}^{2} / \mathrm{g}\right)$ & $<0.5$ \\
XRD main phases & $\mathrm{CuO}, \mathrm{MgAl}_{2} \mathrm{O}_{4}$ \\
\hline
\end{tabular}


Table 2. Properties of coals used in this work.

\begin{tabular}{lcccc}
\hline & Anthracite & $\begin{array}{c}\text { Low Volatile } \\
\text { Bituminous }\end{array}$ & $\begin{array}{c}\text { Medium Volatile } \\
\text { Bituminous }\end{array}$ & Lignite \\
\hline Proximate Analysis (wt.\%) & & & & \\
Moisture & 1.0 & 2.0 & 4.2 & 12.6 \\
Volatile matter & 7.5 & 17.1 & 25.5 & 28.6 \\
Fixed carbon & 59.9 & 68.8 & 55.9 & 33.6 \\
Ash & 31.6 & 12.1 & 14.4 & 25.2 \\
\hline Ultimate Analysis (wt.\%) & & & 69.3 & 45.4 \\
$\mathrm{C}$ & 60.7 & 75.8 & 3.9 & 2.5 \\
$\mathrm{H}$ & 2.1 & 3.7 & 1.9 & 0.6 \\
$\mathrm{~N}$ & 0.9 & 1.9 & 0.9 & 5.2 \\
$\mathrm{~S}$ & 1.3 & 0.4 & 5.4 & 8.5 \\
$\mathrm{O}^{(1)}$ & 2.4 & 4.1 & 25500 & 16250 \\
\hline $\mathrm{LHV}(\mathrm{kJ} / \mathrm{kg})$ & 21900 & 28950 & 2.0 & 1.2 \\
\hline$\Omega_{\text {coal }}(\mathrm{kg} \mathrm{O} / \mathrm{kg}$ coal $)$ & 1.8 & 2.2 & & \\
\hline$(1) \mathrm{Oxyg}$ to balance & & & & \\
\hline
\end{tabular}

${ }^{(1)}$ Oxygen to balance 
Table 3. Operational conditions during experimental work in ICB-CSIC-s1 unit.

\begin{tabular}{|l|c|c|c|c|c|c|}
\hline \multicolumn{1}{|c|}{ Coal } & $\begin{array}{c}\dot{\mathrm{m}}_{\text {coal }} \\
(\mathrm{kg} / \mathrm{h})\end{array}$ & $\begin{array}{c}\dot{\mathrm{m}}_{\mathrm{CuO}} \\
(\mathrm{kg} / \mathrm{h})\end{array}$ & $\begin{array}{c}\phi \\
(-)\end{array}$ & $\begin{array}{c}\lambda \\
(-)\end{array}$ & $\begin{array}{c}\text { Power } \\
(\mathrm{W})\end{array}$ & $\begin{array}{c}\mathrm{m}_{\mathrm{FR}} \\
\left(\mathrm{kg} / \mathrm{MW}_{\text {th }}\right)\end{array}$ \\
\hline Anthracite & 0.10 & 3.1 & 1.1 & 3.1 & 583 & 894 \\
\hline LV Bituminous & 0.10 & 3.7 & 1.0 & 2.7 & 805 & 709 \\
\hline MV Bituminous & 0.08 & 3.2 & 1.1 & 3.6 & 592 & 1003 \\
\hline Lignite & 0.13 & 3.0 & 1.2 & 3.6 & 582 & 845 \\
\hline
\end{tabular}




\section{Caption of figures:}

Fig. 1. Schematic layout of the CLOU system.

Fig. 2. Schematic view of the ICB-CSIC-s1 unit for the CLOU process $\left(1.5 \mathrm{~kW}_{\mathrm{th}}\right)$.

Fig. 3. Evolution of the gas composition in the air and fuel reactor as temperature in the fuel reactor was varied. Coal: lignite, $\dot{m}_{\text {coal }}=0.13 \mathrm{~kg} / \mathrm{h}$

Fig. 4. (a) Combustion efficiency in the fuel reactor and carbon capture efficiency and (b) char conversion, as a function of the fuel reactor temperature obtained with different coals.

Fig. 5. Conversion vs. time curves for combustion in air at $500{ }^{\circ} \mathrm{C}$ of char from the coals used in this work.

Fig. 6. Fractional conversion rate of char for the four different fuels: Lignite (-- $\mathbf{\nabla}--)$, Medium Volatile Bituminous (-- $\mathbf{\Delta}--)$, Low Volatile Bituminous (-- -- ) and Anthracite $(---)$, as a function of fuel reactor temperature.

Fig. 7. Char conversion as a function of the fuel reactor inventory for Lignite at three different efficiencies of the carbon separation system and three temperatures in the fuel reactor: (a) 909 , (b) 935 and (c) $950{ }^{\circ} \mathrm{C} . \eta_{\mathrm{CSS}}: 0(-), 50 \%(\cdots), 90 \%(--) \cdot \phi=1.1 . \dot{m}_{O C}=$ $1.35 \mathrm{~kg} / \mathrm{s}$ per $\mathrm{MW}_{\text {th. }}$.

Fig. 8. Carbon capture efficiency as a function of the fuel reactor inventory for Lignite at three different efficiencies of the carbon separation system and three temperatures in the fuel reactor: (a) 909 , (b) 935 and (c) $950{ }^{\circ} \mathrm{C}$. $\eta_{\mathrm{CSS}}: 0(-), 50 \%(\cdots), 90 \%(--) . \phi=1.1$. $\dot{m}_{O C}=1.35 \mathrm{~kg} / \mathrm{s}$ per $\mathrm{MW}_{\text {th }}$.

Fig. 9. Fuel reactor inventory as a function of the fuel reactor temperature of the different fuels: Lignite (-- $\mathbf{\nabla}--)$, Medium Volatile Bituminous (-- $\boldsymbol{\Delta}$--), Low Volatile Bituminous (-- $\mathbf{- -})$ and Anthracite (-- --$) . \eta_{\mathrm{CC}}=95 \% ; \eta_{\mathrm{CSS}}=90 \% . \phi=1.1$. 


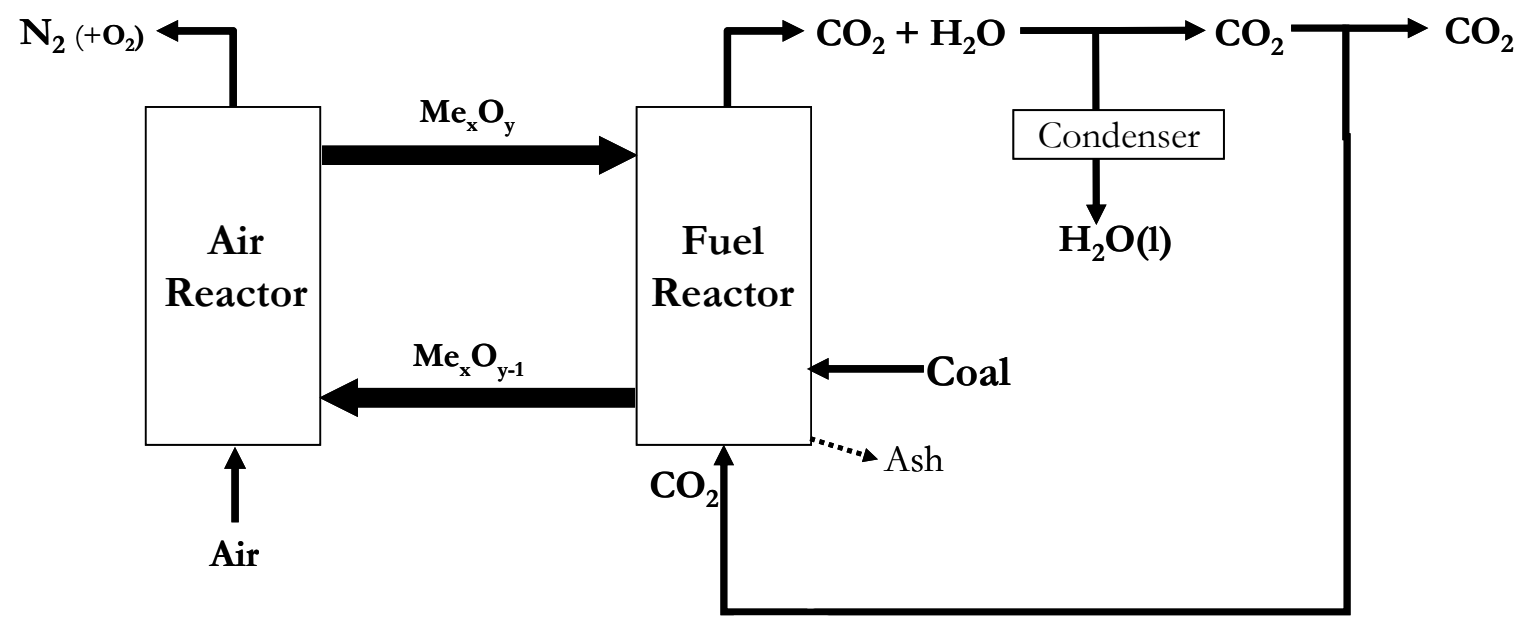

Fig. 1. Schematic layout of the CLOU system. 


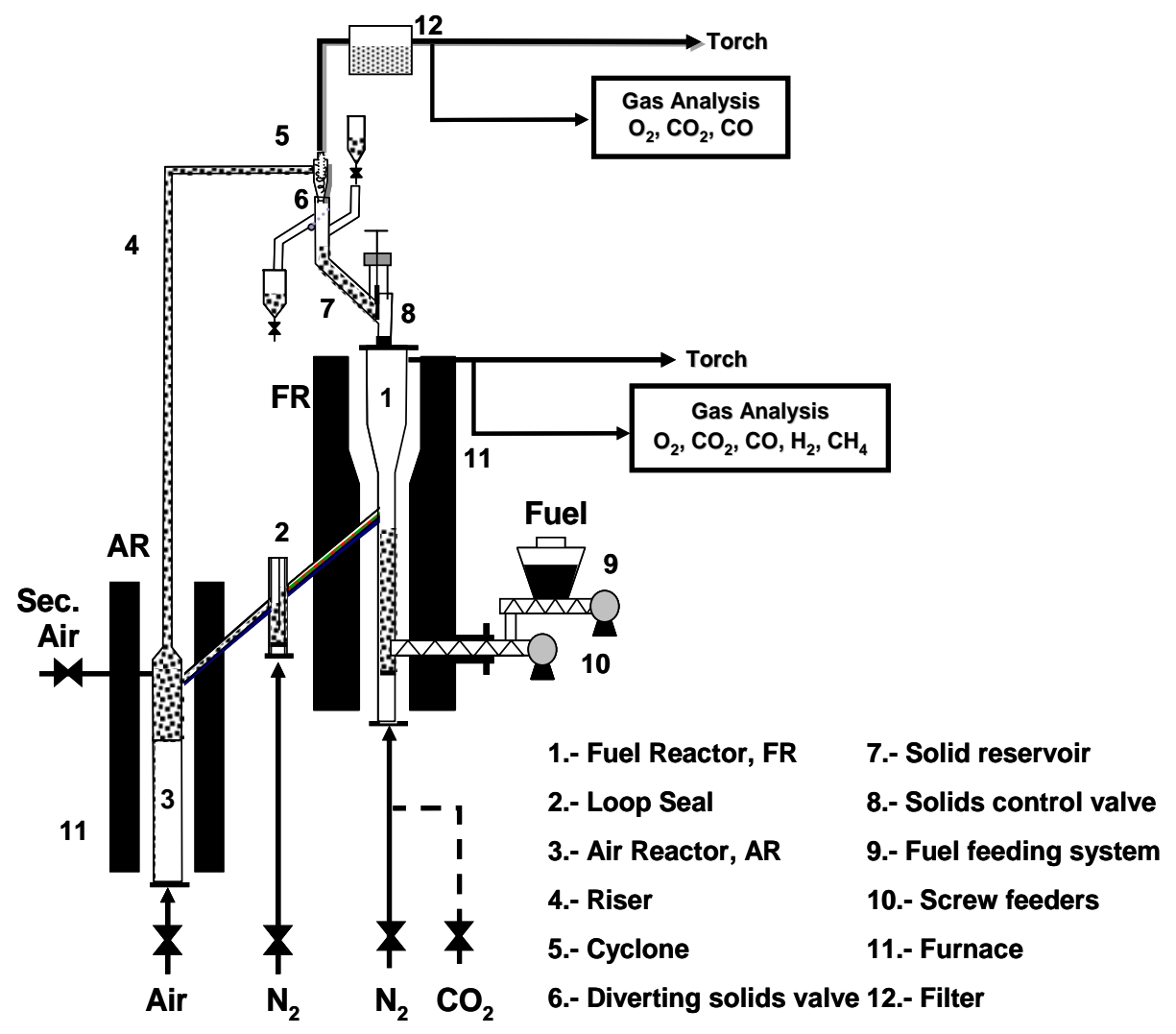

Fig. 2. Schematic view of the ICB-CSIC-s1 unit for the CLOU process $\left(1.5 \mathrm{~kW}_{\text {th }}\right)$. 


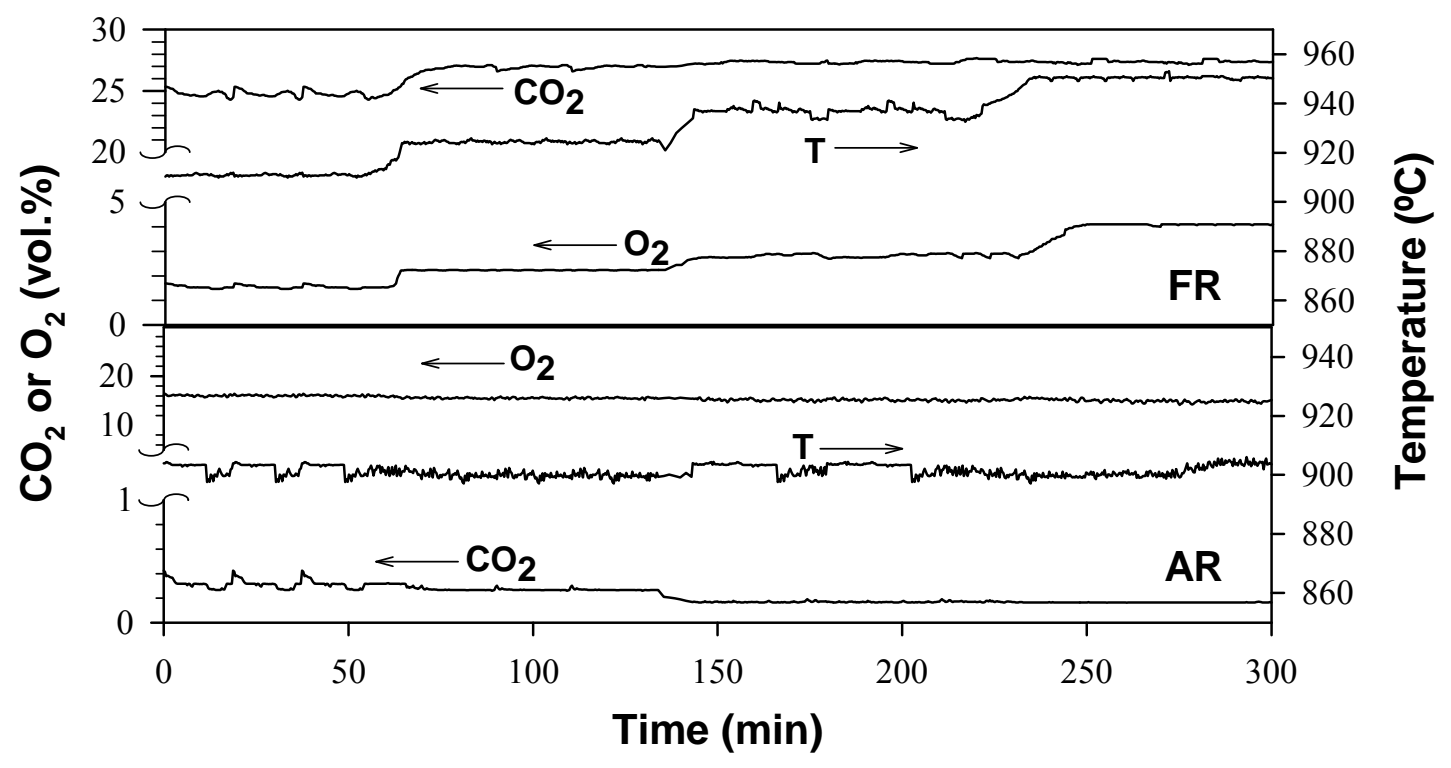

Fig. 3. Evolution of the gas composition in the air and fuel reactor as temperature in the fuel reactor was varied. Coal: lignite, $\dot{m}_{\text {coal }}=0.13 \mathrm{~kg} / \mathrm{h}$. 

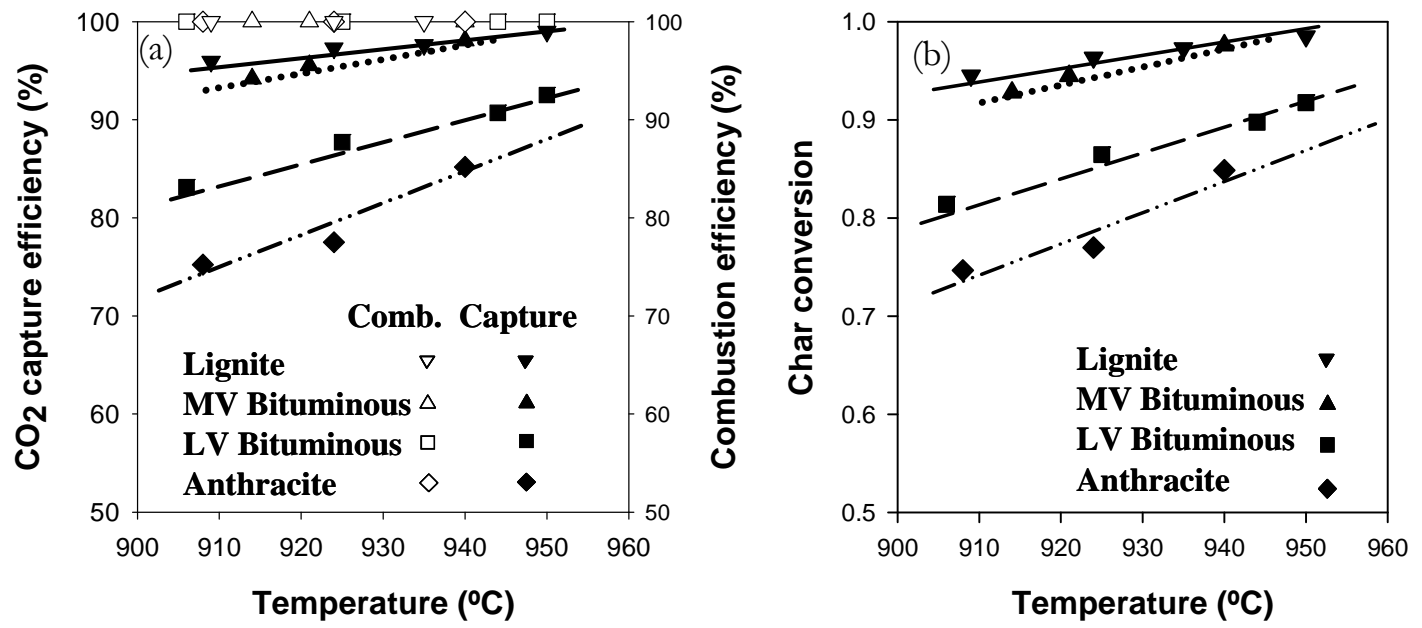

Fig. 4. (a) Combustion efficiency in the fuel reactor and carbon capture efficiency and (b) char conversion, as a function of the fuel reactor temperature obtained with different coals. 


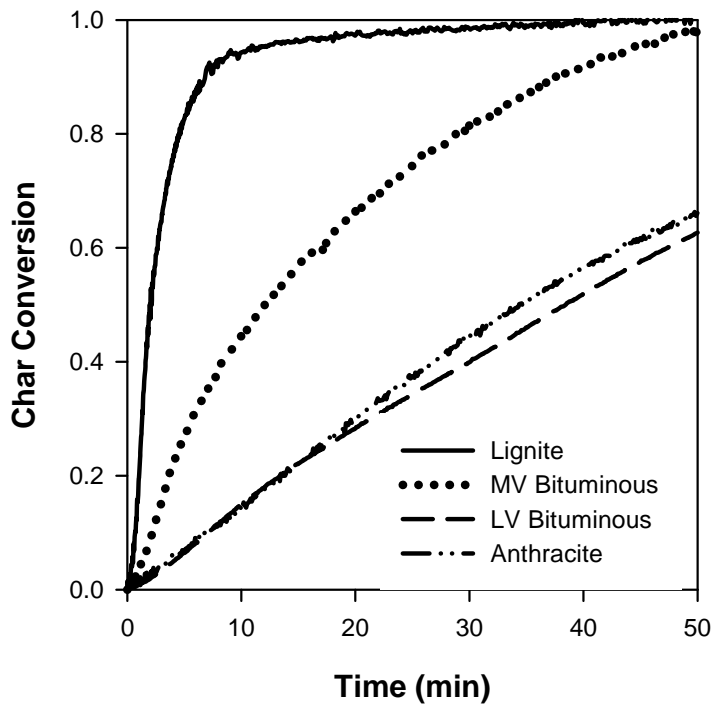

Fig. 5. Conversion vs. time curves for combustion in air at $500{ }^{\circ} \mathrm{C}$ of char from the coals used in this work. 


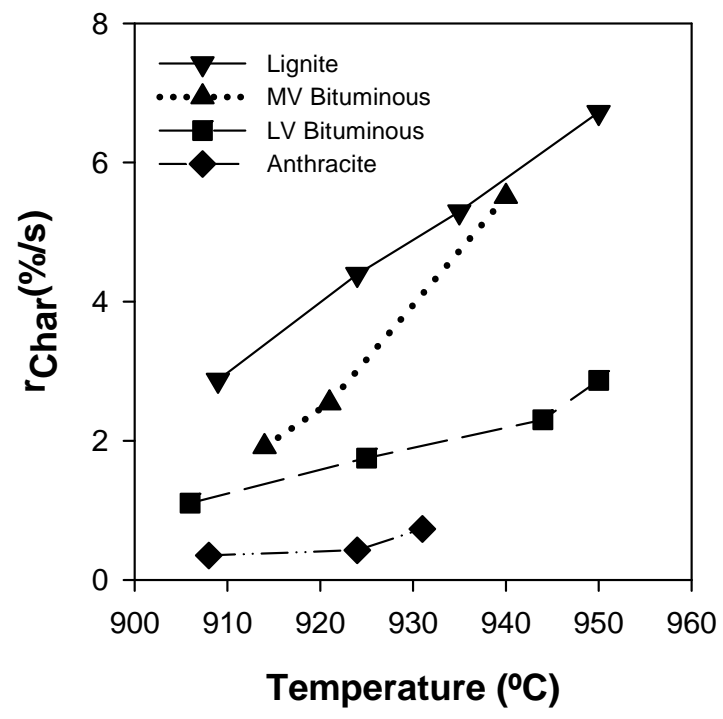

Fig. 6. Fractional conversion rate of char for the four different fuels: Lignite (-- $\mathbf{\nabla - - )}$, Medium Volatile Bituminous (-- $\mathbf{\Lambda}--)$, Low Volatile Bituminous (-- --) and Anthracite $(---)$, as a function of fuel reactor temperature. 


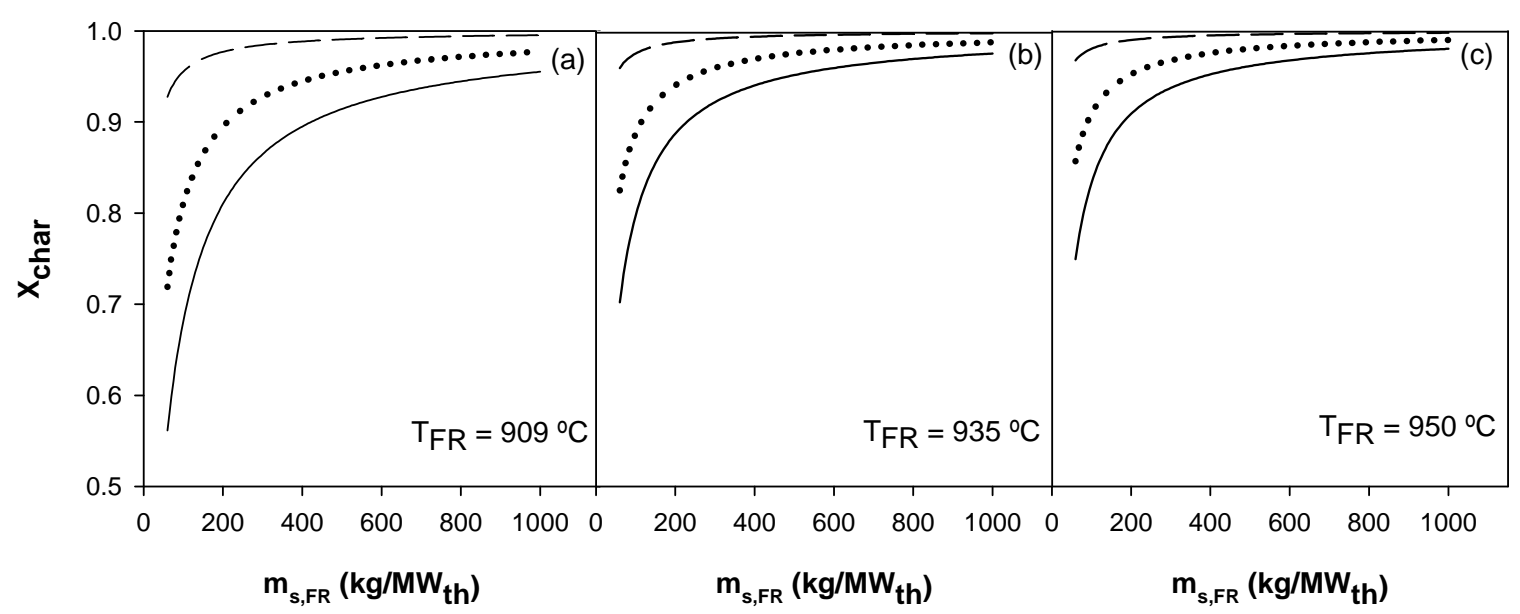

Fig. 7. Char conversion as a function of the fuel reactor inventory for Lignite at three different efficiencies of the carbon separation system and three temperatures in the fuel reactor: (a) 909 , (b) 935 and (c) $950{ }^{\circ} \mathrm{C} \cdot \eta_{\mathrm{CSS}}: 0(-), 50 \%(\cdots), 90 \%(---) \cdot \phi=1.1 \cdot \dot{m}_{O C}=$ $1.35 \mathrm{~kg} / \mathrm{s}$ per $\mathrm{MW}_{\text {th. }}$. 


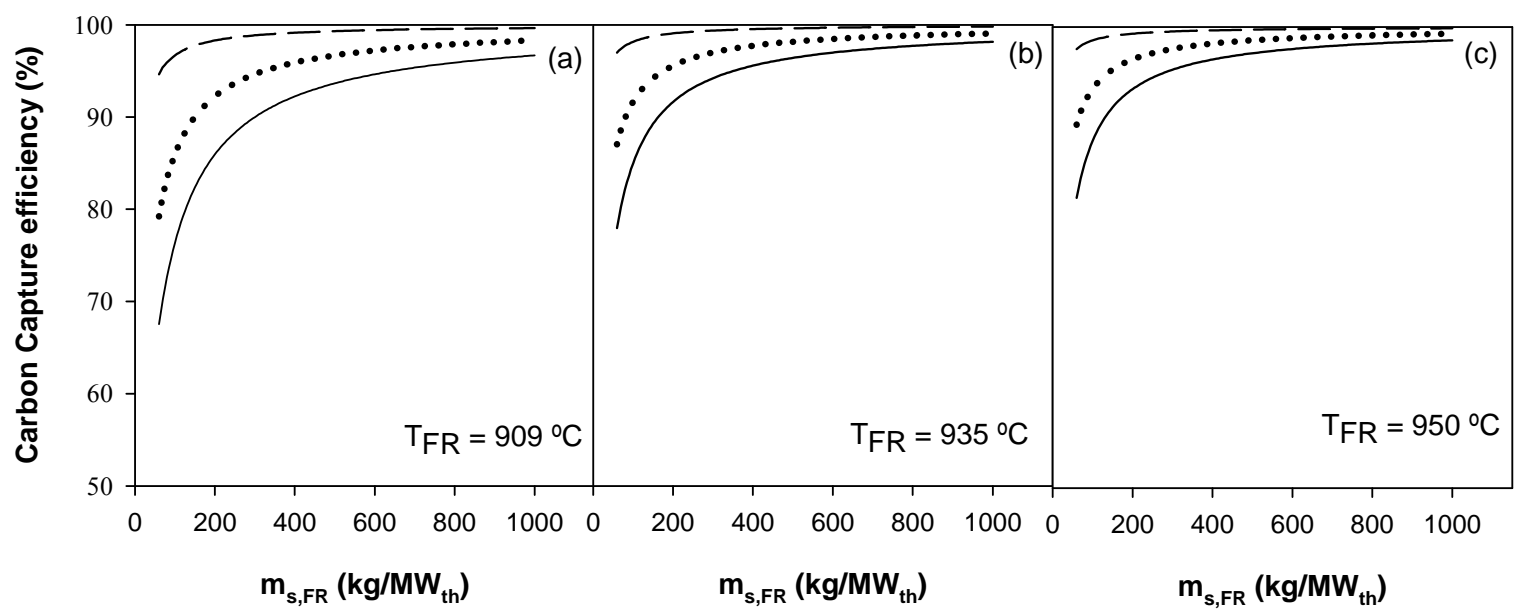

Fig. 8. Carbon capture efficiency as a function of the fuel reactor inventory for Lignite at three different efficiencies of the carbon separation system and three temperatures in the fuel reactor: (a) 909 , (b) 935 and (c) $950{ }^{\circ} \mathrm{C}$. $\eta_{\mathrm{CSS}}: 0(-), 50 \%(\cdots), 90 \%(--) . \phi=1.1$. $\dot{m}_{O C}=1.35 \mathrm{~kg} / \mathrm{s}$ per $\mathrm{MW}_{\text {th }}$. 


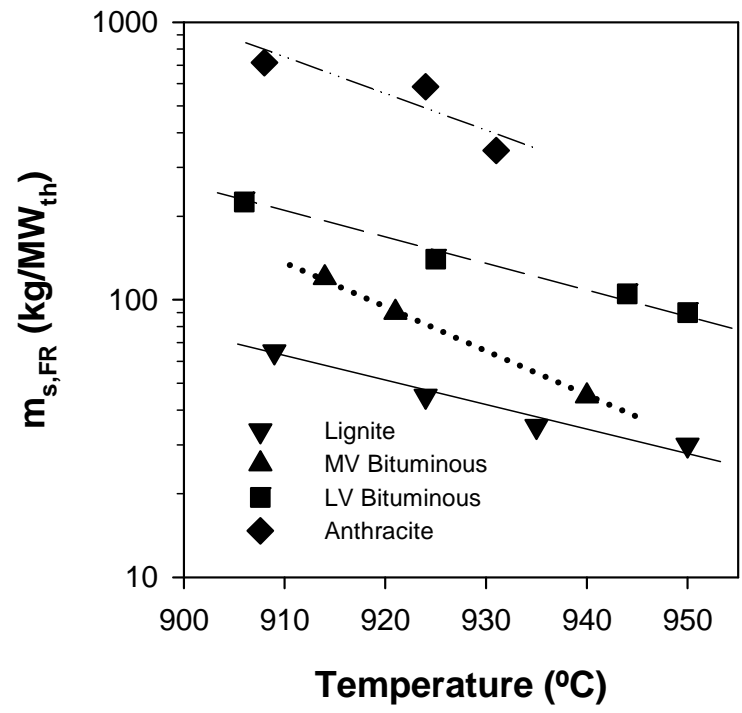

Fig. 9. Fuel reactor inventory as a function of the fuel reactor temperature of the different fuels: Lignite (-- $\mathbf{\nabla}--)$, Medium Volatile Bituminous (-- $\boldsymbol{\Delta}--)$, Low Volatile Bituminous (-- --) and Anthracite (-- --$) . \eta_{\mathrm{CC}}=95 \% ; \eta_{\mathrm{CSS}}=90 \% . \phi=1.1$. 